\title{
KELAYAKAN USAHATANI KEDELAI DI LAHAN DARAT DAN LAHAN SAWAH
}

\section{FEASIBILITY OF SOYBEAN FARMING IN DRYLAND AND WETLAND}

\author{
Rian Kurnia ${ }^{1 *}$, Trisna Insan Noor ${ }^{2}$, Eliana Wulandari², Meddy Rachmadi \\ ${ }^{1}$ Fakultas Pertanian Universitas Galuh \\ ${ }^{2}$ Fakultas Pertanian, Universitas Padjadjaran \\ *Email: kurniarian0@gmail.com
}

(Diterima 24-07-2019: Disetujui 30-07-2019)

\begin{abstract}
ABSTRAK
Penelitian ini bertujuan untuk mengetahui kelayakan usahatani kedelai di lahan darat dan lahan sawah di Kecamatan Jatiwaras Kabupaten Tasikmalaya. Metode yang digunakan dalam penelitian ini adalah metode survey, adapun data yang digunakan terdiri atas data primer dan data sekunder. Penentuan petani sampel menggunakan metode multistage cluster random sampling. Jumlah responden yang diambil sebanyak 36 orang petani yang terbagi petani di lahan darat 21 dan 15 orang petani di lahan wasah. Hasil penelitian menunjukkan bahwa usahatani kedelai di lahan darat lebih layak diusahakan dengan nilai R/C 1,98 sedangkan nilai R/C pada lahan sawah 1,62.

Kata kunci: Strata luas lahan, kelayakan usaha, Biaya produksi, Pendapatan, R-C rasio

\section{ABSTRACT}

This study aims to determine the feasibility of Soybean farming in dryland and paddy fields land in the Jatiwaras Subdistrict, Tasikmalaya Regency. The method used in this study is the survey method, while the data used consists of primary data and secondary data. Determination of sample farmers using the multistage cluster random sampling method. The number of respondents was taken as many as 36 farmers who were divided by farmers on 21 farmers on dryland and 15 farmers on wetland. The results of this study indicate that soybean farming in dryland is more feasible to cultivate with a value of $\mathrm{R} / \mathrm{C} 1.98$ while the value of $\mathrm{R} / \mathrm{C}$ in wetland is 1.62 .
\end{abstract}

Keywords: Land area strata, business feasibility, production costs, income, $R$-C ratio

\section{PENDAHULUAN}

Kedelai merupakan kelompok tanaman pangan yang menjadi komoditas penting dalam kebijakan pertanian setelah padi dan jagung. Hal tersebut sesuai dengan sasaran strategis Kementerian Pertanian tahun 2015-2019, yaitu: pencapaian swasembada padi, jagung dan kedelai serta peningkatan produksi gula dan daging, (2) peningkatan diversifikasi pangan, (3) peningkatan komoditas bernilai tambah dan berdaya saing dalam memenuhi pasar ekspor dan substitusi impor, (4) penyediaan bahan baku bioindustri dan bioenergi, (5) peningkatan pendapatan keluarga petani, dan (6) akuntabilitas kinerja aparatur pemerintah yang baik (Kementan, 2015).

Kedelai memiliki beragam manfaat diantaranya sebagai bahan baku agroindustri tahu, tempe, oncom, tauco, susu kedelai, dan lain-lain. Bagian kedelai 
yang biasanya dimanfaatkan adalah bijinya yang merupakan salah satu sumber protein nabati, kandungan protein kedelai sekitar 35 persen, bahkan pada verietas unggul kadar proteinnya dapat mencapai 40-43 persen.

Rata-rata kebutuhan kedelai per tahun sebanyak 2,2 juta ton. Pemenuhan kebutuhan kedelai sebanyak 67,99 persen diimpor dari luar negeri (Pusat Data dan Sistem Informasi Pertanian Kementerian Pertanian, 2017) (Gambar 1).

\begin{tabular}{|c|c|c|c|c|}
\hline 2.153 .786 & 2.206 .773 & 2.282 .839 & \multicolumn{2}{|c|}{$2.421 .533 \quad 2.533 .056$} \\
\hline 2.107 .792 & $2 \quad 1.787 .632$ & 1.968 .233 & 2.259 .225 & 2.263 .846 \\
\hline 843.153 & 779.992 & 954.997 & 963.183 & 885.575 \\
\hline 2012 & 2013 & 2014 & 2015 & 2016 \\
\hline
\end{tabular}

Sumber: Pusat Data dan Sistem Informasi Pertanian, 2017

\section{Gambar 1. Perkembangan Produksi, Konsumsi dan Impor Kedelai di Indonesia, 2012-2016} (Pusat Data dan Sistem Informasi Pertanian, 2017)

Gambar 1 menunjukkan kesenjangan antara produksi kedelai dan konsumsi kedelai di Indonesia masih sangat jauh. Hal tersebut menunjukan bahwa impor masih menjadi cara untuk memenuhi kebutuhan kedelai dalam negeri. Peningkatan produksi kedelai baik dari kuantitas maupun kualitas terus diupayakan oleh pemerintah, baik ekstensifikasi maupun intensifikasi. Pengembangan komoditas kedelai untuk menjadi komoditas unggulan sub sektor tanaman pangan perlu mendapat dukungan dari semua pihak yang terkait (Pusat Data dan Sistem Informasi Pertanian Kementerian Pertanian, 2017).

Terdapat 16 kabupaten/kota di Jawa Barat yang mengembangkan kedelai, salah satunya adalah Kabupaten Tasikmalaya (Tabel 1).

Tabel 1. Sentra Kedelai di Jawa Barat Tahun 2017

\begin{tabular}{lccl}
\hline Kabupaten & $\begin{array}{c}\text { Luas } \\
\text { Panen (ha) }\end{array}$ & $\begin{array}{c}\text { Produksi } \\
\text { (ton) }\end{array}$ & $\begin{array}{l}\text { Produk } \\
\text {-tivitas } \\
\text { (kw/ha) }\end{array}$ \\
\hline Tasikmalaya & 4.536 & 7.938 & 17,50 \\
Sukabumi & 2.447 & 4.228 & 17,29 \\
Cianjur & 6.467 & 7.954 & 12,30 \\
Garut & 6.170 & 10.137 & 16,43 \\
Indramayu & 22.142 & 40.482 & 18,28 \\
\hline Jawa Barat & 60.172 & 98.938 & 16,44 \\
\hline Indonesia & 589.420 & 887.540 & 15,06 \\
\hline Sumber: BPS, 2018 & & \\
\multicolumn{1}{c}{ Tabel } & 1 & menunjukan & bahwa
\end{tabular}

Kabupaten Tasikmalaya merupakan salah satu kabupaten yang memiliki produktivitas tertinggi setelah Kabupaten Indramayu. Selain itu, Kabupaten Tasikmalaya merupakan pengembangan sentra kedelai di Jawa Barat karena lahan sawah tadah hujan dan lahan darat di wilayah Kabupaten Tasikmalaya memiliki potensi yang cukup besar untuk pengembangan kedelai, baik di lahan masyarakat, perkebunan, kehutanan maupun di lahan Perum Perhutani. Namun, 
potensi tersebut belum diimbangi dengan pengembangan ke arah perubahan dari orientasi produksi ke arah orientasi peningkatan pendapatan petani yang kemudian bertujuan untuk mencapai tingkat kesejahteraan petani.

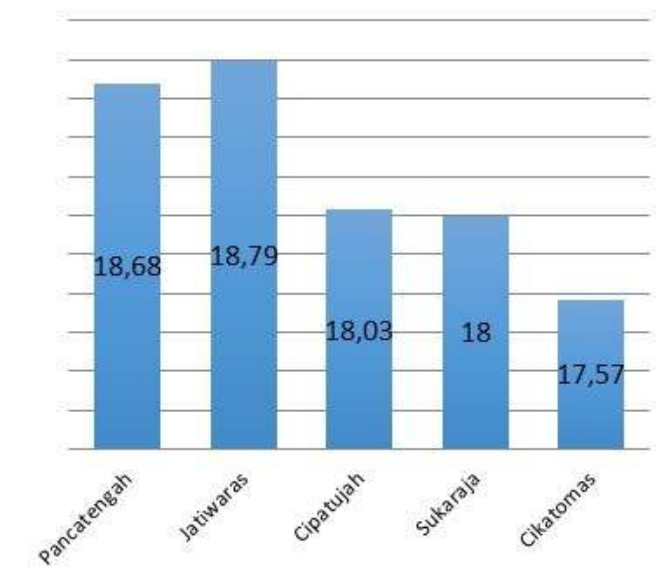

Gambar 2. Lima Kecamatan dengan Produktivitas Kedelai Tertinggi di Kabupaten Tasikmalaya tahun 2017 (BPS Kabupaten Tasikmalaya, 2018)

Gambar 2 menunjukkan bahwa Kecamatan Jatiwaras adalah daerah dengan nilai produktivitas kedelai tertinggi dan merupakan salah satu sentra pengembangan kedelai di Kabupaten Tasikmalaya.

Karakteristik kedelai bersifat lokal spesifik, ditentukan oleh ciri agroekosistem areal tanam. Jamal dan Jumakir (2011) menyebutkan bahwa produktivitas kedelai secara umum dipengaruhi oleh penggunaan varietas kedelai unggul dan penerapan teknologi budidaya kedelai yang sesuai dengan rekomendasi atau anjuran.

Upaya pengembangan kedelai di Kecamatan Jatiwaras menghadapi berbagai kendala dan tantangan, antara lain kekeringan yang diakibatkan curah hujan yang tidak merata sepanjang tahun, belum optimalnya pengendalian OPT, tingkat kesuburan tanah bervariasi dan umumnya rendah-sedang, populasi gulma tinggi, kepastian harga dan pemasaran hasil.

Penelitian ini bertujuan untuk mengetahui, pendapatan, kelayakan finansial, serta pengaruh biaya sarana produksi, strata luas lahan, pendapatan dan $\mathrm{R} / \mathrm{C}$ rasio terhadap usahatani kedelai di Kecamatan Jatiwaran Kabupaten Tasikmalaya.

\section{METODE PENELITIAN}

Metode yang digunakan dalam penelitian ini adalah metode survey pada petani kedelai di Kecamatan Jatiwaras, Kabupaten Tasikmalaya, provinsi Jawa Barat. Teknik pengambilan sampel dilakukan dengan cara multistage cluster random sampling, dengan jumlah sampel 36 orang dengan proporsi 21 petani di lahan darat dan 15 orang petani di lahan sawah, dari populasi petani kedelai sebanyak 185 orang. 
Data yang dikumpulkan dalam penelitian ini bersumber dari data primer dan data sekunder. Data primer diperoleh dari hasil observasi dan wawancara langsung dengan menggunakan daftar pertanyaan (questionare) terhadap responden yaitu responden petani kedelai. Data sekunder diperoleh dari berbagai instansi pemerintah yang terkait dengan penelitian ini dan berbagai literatur lainnya sebagai pendukung dalam penyusunan hasil penelitian. Metode analisis yang digunakan dalam penelitian ini adalah analisis pendapatan, analisis kelayakan dan analisis deskripsi (Soekartawi, 2002).

Biaya usahatani setiap kegiatan usahataninya seorang petani akan diperhadapkan pada masalah beban biaya yang harus dikeluarkan untuk menghasilkan produksi. Adapun biaya dibedakan menjadi dua, yaitu biaya tetap (fixed cost) dan biaya variabel (variable cost). Biaya tetap adalah biaya yang relatif jumlahnya walaupun produksi yang diperoleh banyak atau sedikit. Dengan kata lain, besarnya biaya tetap ini tidak tergantung pada besar kecilnya produksi yang didapat. Dalam penelitian ini, biaya tetap yang dikeluarkan oleh petani terdiri atas biaya pajak dan penyusutan alat.

Biaya variabel adalah biaya yang besar kecilnya dipengaruhi oleh produksi yang dihasilkan. Biaya variabel yang dikeluarkan oleh petani responden dalam penelitian ini adalah biaya benih, pupuk dan tenaga kerja. Biaya tetap dalam konsep operasionalisasi variabel terdiri atas sewa lahan, penyusutan alat dan bunga modal tetap.

Biaya total adalah penjumlahan dari biaya tetap dan biaya variabel. Analisis pendapatan dalam penelitian ini digunakan untuk mengetahui besarnya pendapatan yang diperoleh petani responden usahatani kedelai di Kecamatan Jatiwaras dengan cara menghitung selisih antara total penerimaan dengan total biaya yang dikeluarkan selama satu tahun maka perlu diketahui terlebih dahulu besarnya tingkat penerimaan yang diperoleh serta biayabiaya yang dikeluarkan dahulu besarnya tingkat penerimaan yang diperoleh serta biaya-biaya yang dikeluarkan dalam melakukan suatu usahatani tersebut.

Pendapatan yang diperoleh petani merupakan selisih antara penerimaan total dengan biaya total, biasa dituliskan dalam bentuk persamaan (Soekartawi, 2003):

$$
\Pi=\mathrm{TR}-\mathrm{TC}
$$

Biaya total dalam suatu proses produksi, adalah jumlah biaya variabel total dengan biaya tetap total. Secara matematika dapat ditulis dengan rumus: 


$$
\mathrm{TC}=\mathrm{FC}+\mathrm{VC}
$$

Penerimaan yang didapatkan petani merupakan hasil kali dari produksi (Y) yang diperoleh petani dengan harga jualnya (Py) pada waktu panen, yang biasa ditulis dengan persamaan (Soekartawi, 2003):

$$
\mathrm{TR}=\mathrm{Y} . \mathrm{Py}
$$

Tingkat kelayakan dianalisis dengan $\mathrm{R} / \mathrm{C}$ rasio yang secara matematis dapat ditulis sebagai berikut (Hadisapoetro, 1973):

$$
\mathrm{R} / \mathrm{C} \text { Ratio }=\frac{\text { Total penerimaan }}{\text { Total biaya }}
$$

Indikator kelayakan usaha berdasarkan metode $\mathrm{R}-\mathrm{C}$ ratio dapat digunakan kriteria sebagai berikut:

$\mathrm{R} / \mathrm{C}>1$ : Usahatani menguntungkan dan layak untuk diusahakan

$\mathrm{R} / \mathrm{C}=1$ : Usahatani impas (tidak untung, tidak rugi)

$\mathrm{R} / \mathrm{C}<1$ : Usahatani rugi dan tidak layak untuk diusahakan

Modal yang digunakan merupakan modal sendiri. Mulyadi menyatakan bahwa, tidak ada perbedaan apapun antara modal sendiri dengan modal pinjaman karena masing-masing menyumbang langsung kepada produksi.

\section{HASIL DAN PEMBAHASAN}

Kecamatan Jatiwaras merupakan daerah penghasil kedelai, walapun jumlah petani kedelai terus berkurang dari tahun ke tahun. Seperti umumnya di wilayah kecamatan lainya di Jawa Barat, maka luas lahan untuk pertanaman kedelai ini tergolong sempit, sehingga merupakan kelemahan bagi petani karena usahatani dengan lahan sempit kurang dapat memberikan keuntungan yang cukup bagi petani dan keluarganya untuk hidup layak jika tidak diimbangi dengan penghasilan dari kegiatan usaha ekonomi lainnya, Sebaliknya, jika semakin tinggi luas lahan untuk usahatani kedelai, maka ada kecenderungan untuk menghasilkan produksi yang semakin tinggi (Hernanto, 1991 dalam Supartama, dkk, 2013).

Wilayah Kecamatan Jatiwaras di Kabupaten Tasikmalaya merupakan sentra produksi kedelai dengan produksitivitas yang baik, karena selain daerahnya cocok untuk usahatani kedelai juga penggunaan benih kedelai yang berkualitas unggul dan bermutu. Walapun produktivitas hasil kedelai masih di bawah 2 ton/ha, namun di wilayah ini produktivitasnya masih di atas rata-rata nasional yang hanya sekitar 1,6 ton/ha (Anonim, 2015). Angka ini tentu akan memberikan kontribusi yang sangat besar pada penerimaan usahatani jika 
harga jual produksi kedelai tidak mengalami fluktuasi atau penurunan harga.

Input produksi usahatani kedelai seringkali disebut sebagai korbanan produksi, kerena input produksi tersebut dikorbankan untuk menghasilkan produksi maka diperlukan pengetahuan mengenai hubungan antara input produksi yaitu kesiapan lahan, tenaga kerja, benih, pupuk, penggunaan pestisida, pengairan, dan produksi (output). Luas lahan adalah besarnya luasan lahan yang dikelolah dalam berusahatani untuk menghasilkan produksi. Berdasarkan hasil penelitian luas lahan yang digarap petani yaitu kurang dari 1 ha. Pendapat Hernanto (1991) dalam Supartaman (2013) bahwa tanah yang sempit merupakan kelemahan yang cukup besar bagi petani, dengan kata lain usahatani pada lahan yang sempit kurang dapat memberikan keuntungan yang cukup bagi petani dan keluarga untuk hidup layak. Sebaliknya, semakin tinggi suatu luas lahan, maka kecenderungan untuk menghasilkan produksi semakin tinggi. Biaya produksi, pendapatan dan $\mathrm{R} / \mathrm{C}$ usahatani kedelai di lahan darat dan sawah dapat dilhat pada Tabel 2.

Tabel 2. Nilai Produksi, Biaya Produksi, Pendapatan Usahatani dan R/C Lahan Sawah dan Lahan Darat per Hektar per Satu Musim Tanam

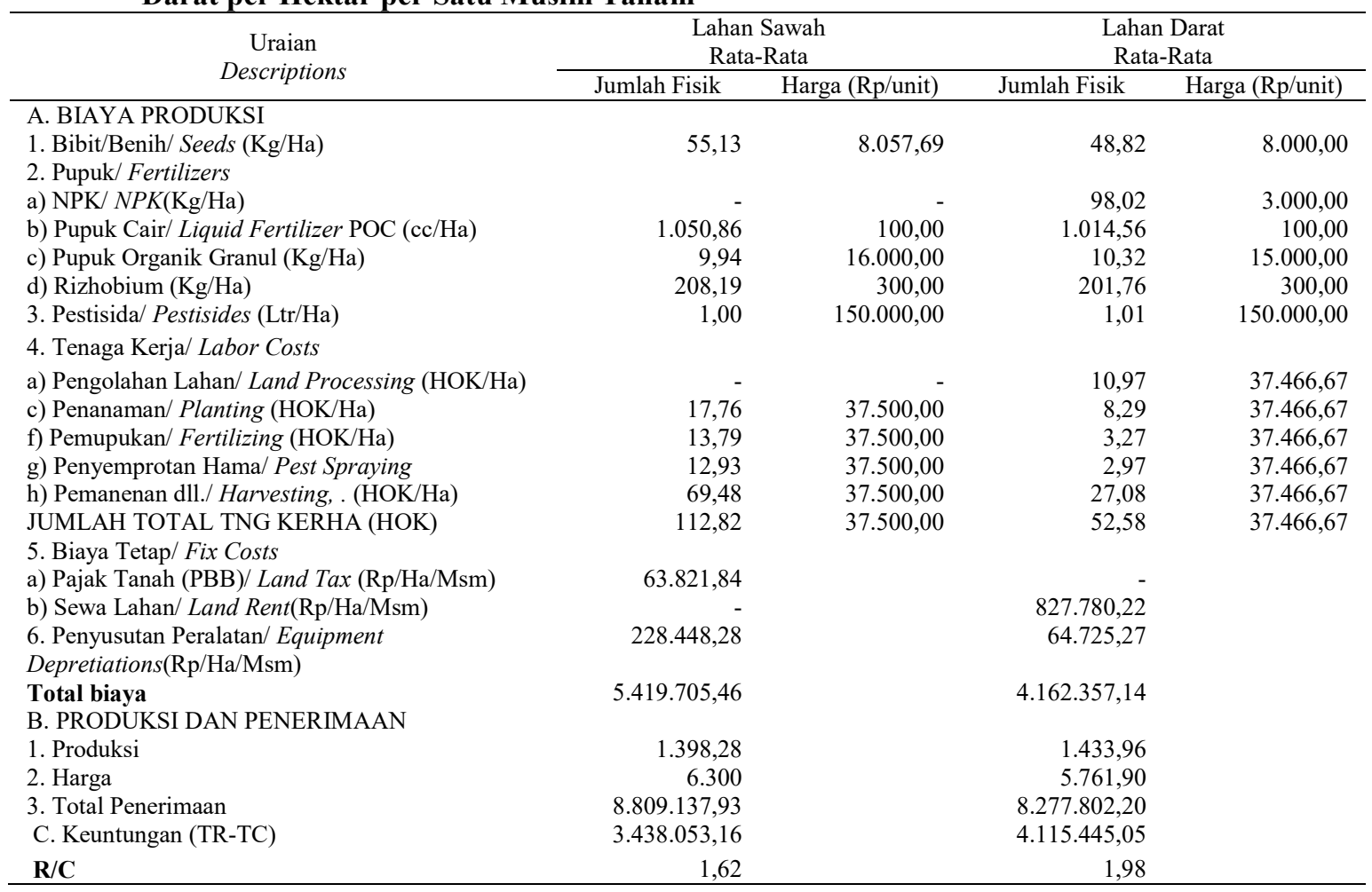


Biaya usahatani kedelai yaitu biaya yang dikeluarkan oleh petani responden, semua pengeluaran yang dinyatakan dengan uang yang diperlukan untuk menghasilkan sesuatu produk dalam suatu periode produksi. Nilai biaya dinyatakan dengan uang (rupiah). Biaya usahatani kedelai di lahan sawah berbeda dengan di darat. Biaya total usahatani di lahan sawah sebesar Rp 5.419.705,46, sedangkan di lahan darat sebesar $\mathrm{Rp} \quad 4.162 .357,14$. Biaya usahatani kedelai sangat dipengaruhi oleh tingkat penggunaan sarana produksi, seperti benih, pupuk, pestisida, dan tenaga kerja.

Harga kedelai sangat ditentukan oleh berbagai faktor, antara lain kualitas kedelai yang dihasilkan, kepada siapa petani menjual, juga ketersediaan kedelai di pasar. Kelemahan mekanisme harga produk pertanian adalah harga rendah pada saat panen raya karena pasokan berlimpah. Pada saat penelitian, harga kedelai di tingkat petani bervariasi antara $\mathrm{Rp}$
$5.000 / \mathrm{kg}$ - Rp.7.500/kg. Namun harga kedelai tidak jauh berbeda jika dibandingkan harga kedelai berdasarkan agroekositem kedelai di lahan sawah dan kedelai di lahan darat, tidak jauh berbeda. Rata-rata harga kedelai di lahan sawah sebesar Rp 6.300,00/kg sedangkan di lahan darat sebesar Rp 5.761,90/kg. Rata-rata hasil produksi untuk lahan sawah adalah 1.398,28 kg per hektar, dan produksi lahan darat $1.433,96 \mathrm{~kg}$ per hektar. Dari harga dan produksi, maka petani di lahan sawah mendapatkan penerimaan sebesar $\mathrm{Rp}$ 8.809.137,93 dan Rp 8.277.802,20 untuk petani lahan darat.

Penerimaan usahatani yang tinggi belum berarti diikuti oleh biaya produksi yang tinggi. Penerimaan petani lahan sawah lebih tinggi dibandingkan dengan petani di lahan darat yang disebabkan oleh produksi dan harga jual kedelai yang lebih tinggi, tapi di sisi lain biaya produksi petani di lahan sawah juga lebih tinggi. 
Dalam hal ini, yang penting bagi petani adalah tingkat pendapatannya.

Rata-rata pendapatan usahatani

kedelai di lahan sawah sebesar Rp 3.438.053,16, sedangkan rata-rata pendapatan usahatani kedelai di lahan darat sebesar $\mathrm{Rp}$ 4.115.445,05, hal ini menunjukan bahwa usahatani kedelai baik di lahan sawah maupun lahan darat samasama menguntungkan. Pendapatan usahatani kedelai di lahan darat lebih tinggi dibandingkan lahan sawah yang disebabkan oleh karena biaya usahatani kedelai di lahan darat lebih kecil.

Indikator lainnya yang digunakan untuk menilai kinerja usahatani adalah $\mathrm{R} / \mathrm{C}$, yaitu rasio antara penerimaan dan biaya yang dikeluarkan. Semakin besar $\mathrm{R} / \mathrm{C}$ maka usahatani tersebut semakin menguntungkan dan layak untuk dilakukan. $\mathrm{R} / \mathrm{C}$ rata-rata usahatani lahan sawah adalah 1,62 dan untuk usahatani lahan darat 1,98, menunjukan bahwa R/C $>1$ maka usahatani kedelai di Kecamatan
Jatiwaras Kabupaten Tasikmalaya dikatakan layak. Hasil penelitian ini sejalan dengan penelitian Zakaria (2009), yang menunjukkan bahwa kegiatan usahatani kedelai di tingkat petani adalah layak diusahakan karena nilai imbangan pendapatan dan biaya $(\mathrm{R} / \mathrm{C})$ lebih dari satu. Nuswantara, dkk (2016) melakukan penelitian di Desa Kebinagung Kabupaten Grobogan dan menunjukkan hasil nilai $\mathrm{R} / \mathrm{C}$ dari usahatani kedelai sebesar 1,29.

$\mathrm{R} / \mathrm{C}$ petani di lahan sawah 1,62 dan petani di lahan darat 1,98 menunjukkan bahwa setiap rupiah biaya yang dikeluarkan akan memperoleh penerimaan sebesar 1,62 rupiah untuk petani di lahan sawah serta 1,98 rupiah untuk petani di lahan darat. Selain faktor R/C juga ditentukan interaksi dari faktor kuantitas produksi kedelai per musim tanam dan faktor biaya produksi per musim tanam, luasan lahan juga menjadi faktor yang mempengaruhi besarnya $\mathrm{R} / \mathrm{C}$.

\section{KESIMPULAN}

Keragaan usahatani di Kecamatan Jatiwaras memiliki perbedaan dari segi budidaya dan pengganaan sarana produksi, khususnya perlakuan olah tanah yang 
dilakukan oleh petani lahan darat sedangkan petani di lahan sawah tidak melakukannya. Usahatani di lahan sawah dan darat layak diusahakan dilihat dari $\mathrm{R} / \mathrm{C}$ rata-rata usahatani lahan sawah adalah 1,62 dan untuk usahatani lahan darat 1,98, dengan $\mathrm{R} / \mathrm{C}>1$.

\section{DAFTAR PUSTAKA}

Anonym, 2015. Outlook komoditas pertanian tanaman pangan kedelai. Pusat data dan sistem informasi pertanian. Kementrian pertanian.

BPS Jawa Barat. 2016 . Jawa Barat dalam Angka 2016. Badan Pusat Statistik Provinsi Jawa Barat.

Direktorat Pangan dan Pertanian. 2013. Rencana Pembangunan Jangka Menengah Nasional (RPJMN) Bidang Pangan dan Pertanian 20152019.

www.bappenas.go.id/index.php/dow nload_file/view/15718/4661/. Diakses tanggal 5 Januari 2017.

Harsono. 2000. Kapita Selekta Neurologi. Gadjah Mada. Yogyakarta: University Press.
Marwoto dan Y. Hilman. 2005. Teknologi kacang-kacangan dan umbi-umbian mendukung ketahanan pangan. Kinerja Balitkabi 2003-2004. Balitkabi. $20 \mathrm{hlm}$.

Mulyadi. 1991. Akuntansi Biaya. Edisi Kelima. Aditya Media. Yogyakarta.

Nazir, M. 2005. Metode Penelitian. Ghalia Indonesia. Bogor Selatan

Soekartawi. 2002. Ilmu Usahatani. Jakarta. . 2003. Prinsip ekonomi pertanian. Jakarta: Rajawali Press.

Soedarsono H, 1973. Ilmu Usahatani, UGM press, Yogyakarta.

Supandi. 1988. Potensi Pengembangan Palawija dalam pola Tanam Padi di Wilayah Pengairan Jatiluhur. Jurnal Litbang Pertanian 8: 10-15.

Supartma, dkk. 2013. Analisis pendapatan dan kelayakan usahatani padi sawah di suabak baturiti desa balinggi kecamatan balinggi kabupaten parigi mouton. Jurnal agroteknologi 1(2): 166-172.

Sasa, J.J. \& S. Partohardjono. 2000. Kelayakan Pola Tanam Konservasi di Mikro Daerah Aliran Sungai Hargomulyo, Kulonprogo, Jawa Tengah. Penelitian Pertanian Tanaman Pangan 19: 115-122. 